\title{
Accuracy in fixing ship's positions by camera survey of bearings
}

\author{
Krzysztof Naus, Mariusz Wą̇̇ \\ Institute of Navigation and Hydrography \\ Polish Naval Academy \\ 69 Smidowicza St., 81-103 Gdynia, Poland \\ e-mail: K.Naus@amw.gdynia.pl,mwaz@amw.gdynia.pl
}

Received: 21 October 2010 /Accepted: 9 March 2011

\begin{abstract}
The paper presents the results of research on the possibilities of fixing ship position coordinates based on results of surveying bearings on navigational marks with the use of the CCD camera. Accuracy of the determination of ship position coordinates, expressed in terms of the mean error, was assumed to be the basic criterion of this estimation.

The first part of the paper describes the method of the determination of the resolution and the mean error of the angle measurement, taken with a camera, and also the method of the determination of the mean error of position coordinates when two or more bearings were measured. There have been defined three software applications assigned for the development of navigational sea charts with accuracy areas mapped on.

The second part contains the results of studying accuracy in fixing ship position coordinates, carried out in the Gulf of Gdansk, with the use of bearings taken obtained with the Rolleiflex and Sony cameras. The results are presented in a form of diagrams of the mean error of angle measurement, also in the form of navigational charts with accuracy fields mapped on.

In the final part, basing on results obtained, the applicability of CCD cameras in automation of coastal navigation performance process is discussed.
\end{abstract}

Keywords: coastal navigation, position accuracy, camera survey of an angle

\section{Introduction}

Carrying out coastal navigation process, a navigator visually identifies navigational marks, situated within his visibility range. He takes measurements of bearings and distances towards the marks. He sets out ship position coordinates using the analytic and graphical methods based on the survey results. To obtain coordinates of ship positions the navigator operates the measuring equipment and processes visual signals using information about navigational marks, coming from nautical publications.

Until now no attempts of automation of the navigator's actions have been undertaken, although there were invented high-resolution visual cameras - which may be capable to provide an aid in identification and survey, electronic navigational charts - containing information on navigational signing in digital form, computers of high computing power - to enable processing visual displays in real time. 
The implementation of new technology in navigation requires an intensive research. It should concern, for example, the possibility of developing digital methods of automatic identification of navigational marks on the basis of the coast images sequence and electronic navigational chart, or estimation of accuracy of the determination of ship position coordinates, on the basis of survey of distances and bearings towards navigational marks with the use of high resolution CCD cameras. It could further result in wider investigations concerning the application of the optical systems to automation of coastal navigation processes.

In recent years, image recognition and its use as a primary source of information about the environment is the subject of numerous studies especially in the field of photogrammetry and robotics - interdisciplinary field of knowledge, acting on the contact mechanics, automation, electronics, cybernetics and computer science. Particularly noteworthy are studies on

- active visual information analysis conducted by the Robotic Research Group, University of Oxford (Knight, 2002; Davison, 2003) and the University of Texas (Stronger and Stone, 2007; Sridharan et al., 2005),

- automation of the process of determining the elements for the external orientation of the test conducted OEEPE (OEEPE, 1999; Jędryczka, 1999),

- model design environment (Mouragnon, 2006; Yuanand and Medioni, 2006),

- techniques for SLAM (Simultaneous Localisation and Called Mapping), conducted by the Laboratory Carneggie Mellon University (Montemerlo, 2003; Stachniss et al., 2004; Wang, 2004),

- location-based Monte-Carlo method (Robert, 2004),

- examination of the use of omnidirectional camera (Winters et al., 2001; Benhimmane and Mailis, 2006),

- increase the resistance of the localization process to errors (Austin and Kouzoubov, 2002; Bianco and Zelinsky, 2000).

In the maritime navigation, image processing techniques are currently used only to visualize the ENC (Electronic Navigational Chart) in ECDIS (Electronic Chart Display and Information System), to fix a vessel position based on a radar image with the coastline (the so-called comparative navigation), and to visualize sonar images of the seabed.

Generally, a few studies related to image processing, refer only to automation of the process of conducting a vessel along the fairway, navigation line, in particular a light sector (Hoshizaki et al., 2004; Snyder et al., 2004; Ryynanen et al, 2007). There is a lack of research on the comparative optical system designed to automate the process of determining the position coordinates of the ship manoeuvring in the coastal zone.

The paper presents preliminary studies on the comparative optical system, the possibility of using CCD cameras for measurements performed on the ship board to the navigational marks. Accuracy of fixing ship position coordinates, applying bearings' measurements taken with Rolleiflex and Sony cameras has been evaluated. 


\section{Experimental procedures}

While planning a ship's route, a navigator, as a rule, faces a problem of determining position's accuracy not only with respect to selected reference points but also to a whole area of the intended navigation route. Thus, the determination of the area, where the position accuracy is more strict than the set one, becomes essential. Depending on the fixing position method, the accuracy area's boundaries are set out using various manners, although basing on the same assumptions, i.e, setting out geometrical location of the points of equal position accuracy.

The basic parameter, applied in navigation to estimate position coordinates accuracy, is the mean error. For angular measurements taken with a camera it is the mean error of coordinates of a position, set out from two or more bearings towards navigational marks observed (in surveying the method is known as angular intersection).

Knowing the mean error's value at every point of the sea, each basin can be partitioned into areas where accuracy of the position is within a certain assumed range. Placing the areas on a marine navigational chart yields a navigator the information whether the accuracy of the position being currently fixed is appropriate for coastal navigation, ports approaching and port navigation.

The methods of calculation, adopted for evaluation of the angle measurement accuracy method and coordination of the position fixed from two or more bearings towards camera-observed navigational marks, is presented hereunder in sections 2.1 and 2.2. The applications used for preparing sea navigational charts with accuracy areas mapped on are specified in section 3 .

\subsection{Method of calculation of parameters for evaluation of accuracy of angle surveying camera}

Accuracy of angle survey with the use of a camera can be expressed by two parameters: resolution and the mean error. The values of those parameters depend mainly on potentialities of focusing optical systems and a size of pixel $r$ in their CCD matrixes (Charge Coupled Device). The focusing possibilities define "power of concentration" of light rays. The shorter is the focal length, the more refracted are the rays, getting intensely focused, what causes increasing of distance to the display and lowering accuracy of the survey. Sizes of singular pixels in contemporary CCD matrixes range from 3 up to $14 \mu \mathrm{m}$. A smaller size of a pixel enables better projection of display details and thereby an increase of survey accuracy. Figure 1 presents a concept of camera survey of bearing.

The formula describing the bearing survey resolution $D$ can easily be derived by means of similarity of the triangles $\mathrm{AOB}$ and $\mathrm{aOb}$

$$
D=\frac{r \cdot Z}{f}
$$




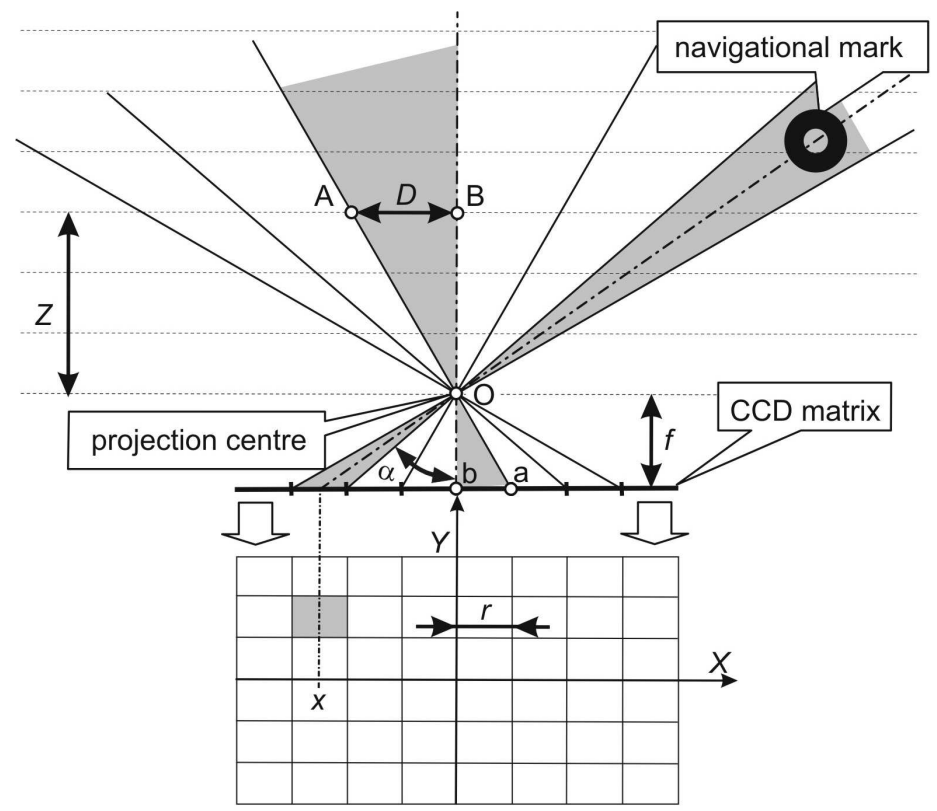

Fig. 1. Concept of camera survey of bearings

The mean error of measured angle is determined by applying the mean errors propagation law. Since

$$
\alpha=\arctan \left(\frac{x}{f}\right)
$$

then knowing mean errors $m_{f}, m_{x}$ of independent variables $f$ (focal distance), and $x$ (distance measured on a CCD matrix), respectively, and computing partial derivatives of (2) with respect to them, one obtains

$$
m_{\alpha}=\left[\left(-\frac{x}{f^{2}+x^{2}} \cdot m_{f}\right)^{2}+\left(\frac{f}{f^{2}+x^{2}} \cdot m_{x}\right)^{2}\right]^{1 / 2}
$$

or

$$
m_{\alpha}=\left[\left(-\frac{\tan \alpha}{f\left(1+\tan ^{2} \alpha\right)} \cdot m_{f}\right)^{2}+\left(\frac{1}{f\left(1+\tan ^{2} \alpha\right)} \cdot m_{x}\right)^{2}\right]^{1 / 2}
$$

\subsection{The method of calculation of the mean error values in ship position coordinates, fixed using the camera surveyed bearings}

According to the requirements of the International Maritime Organization (IMO) described in the Resolution A.424 and SOLAS Convention, ships of tonnage of 500 BRT 
and larger have to be equipped with a gyrocompass (International Maritime Organization, 1974, 1979). The equipment is used to survey an angle, e.g. a course angle or a bearing angle.

If a camera is coupled with the gyrocompass, then such a measurement system can be used for surveying bearings towards observed navigational marks (Fig. 2).

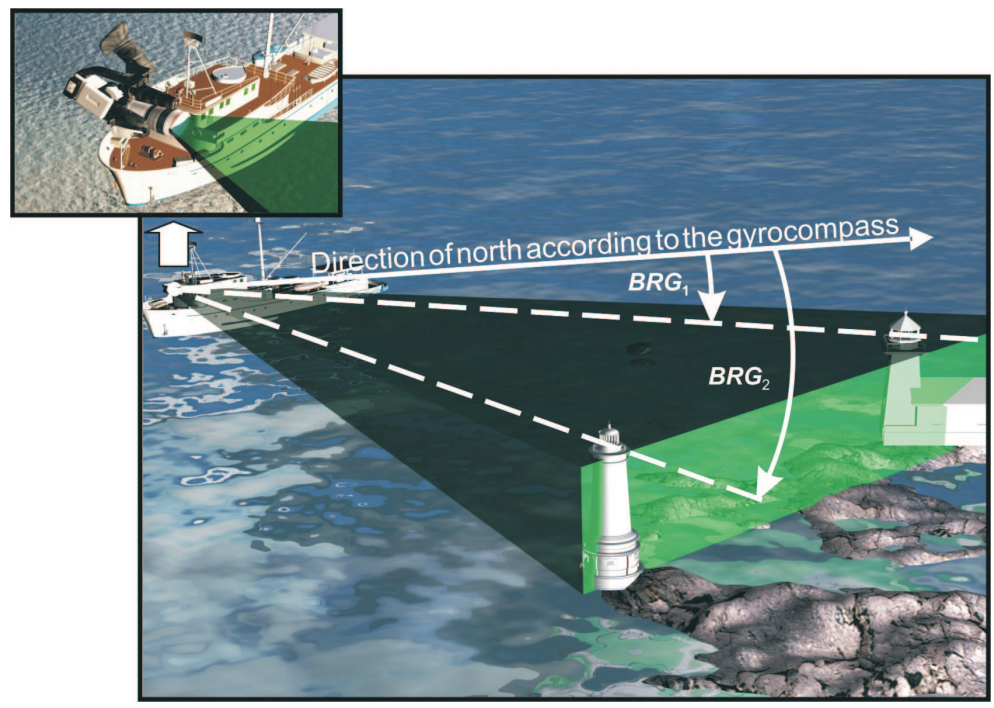

Fig. 2. Principle of survey of bearings with a gyrocompass-camera system

Basing on the bearings survey and the known geographical coordinates of navigational marks, a ship position can be fixed. The mean error of the position obtained from two bearings $B R G_{1}$ and $B R G_{2}$ can be expressed with the following formula (Kopacz et al., 2003; Jagielski, 2007)

$$
m_{\text {pos }}=\frac{\left(D_{1}^{2} \cdot m_{B R G_{1}}^{2}+D_{2}^{2} \cdot m_{B R G_{2}}^{2}\right)^{1 / 2}}{\sin \left(B R G_{2}-B R G_{1}\right)}
$$

where $m_{B R G_{1}}=\left(m_{G}^{2}+m_{\alpha_{1}}^{2}\right)^{1 / 2} ; m_{B R G_{2}}=\left(m_{G}^{2}+m_{\alpha_{2}}^{2}\right)^{1 / 2} ; D_{1}, D_{2}$ - distance from the fixed ship position to the first mark and to the second mark, respectively; $m_{G}$ - the mean error in the gyrocompass surveyed direction, usually adopted to be at a level of $\pm 1^{\circ}$.

When determining the position from three and more bearings, the use of the LS method of adjustment is required to enable fixing an optimum position of the ship. Classical adjustment formulae are as follows (Wiśniewski, 2005)

$$
\left.\begin{array}{l}
\mathbf{V}=\mathbf{A} \hat{\mathbf{d}}_{\mathbf{x}}+\mathbf{L}-\text { functional model } \\
\mathbf{C}_{\mathbf{x}}=\delta_{0}^{2} \mathbf{P}^{-1}-\text { stochastic model } \\
\mathbf{V}^{\mathrm{T}} \mathbf{P V}=\text { min }- \text { adjustment criterion }
\end{array}\right\}
$$


where A - design matrix; $\hat{\mathbf{d}}_{\mathbf{x}}$ - estimator of measured values; $\mathbf{L}$ - vector of observations; $\delta_{0}^{2}$ - variance coefficient; $\mathbf{P}$ - weight matrix.

The mean error of the adjusted ship position is computed as follows

$$
m_{\text {pos }}=\left(m_{\hat{X}_{S}}^{2}+m_{\hat{Y}_{S}}^{2}\right)^{1 / 2}
$$

where $m_{\hat{X}_{S}}, m_{\hat{Y}_{S}}$ are mean errors of adjusted coordinates $\left(\hat{X}_{s}, \hat{Y}_{s}\right)$ of the ship position, that are the estimators of the covariance matrix

$$
\hat{\mathbf{C}}_{\hat{\mathbf{X}}}=\hat{\delta}_{0}^{2}\left(\mathbf{A}^{\mathrm{T}} \mathbf{P A}\right)^{-1}=\left[\begin{array}{cc}
m_{\hat{X}_{S}} & \operatorname{cov}\left(\hat{X}_{s}, \hat{Y}_{s}\right) \\
\operatorname{cov} v\left(\hat{Y}_{s}, \hat{X}_{s}\right) & m_{\hat{Y}_{S}}
\end{array}\right]
$$

where

$$
\mathbf{A}=\left[\begin{array}{cc}
\frac{\Delta y_{1}}{D_{1}^{2}} & -\frac{\Delta x_{1}}{D_{1}^{2}} \\
\frac{\Delta y_{2}}{D_{2}^{2}} & -\frac{\Delta x_{2}}{D_{2}^{2}} \\
\vdots & \vdots \\
\frac{\Delta y_{n}}{D_{n}^{2}} & -\frac{\Delta x_{n}}{D_{n}^{2}}
\end{array}\right], \quad \mathbf{P}=\left[\begin{array}{cccc}
\frac{1}{m_{B R G_{1}}^{2}} & 0 & \cdots & 0 \\
0 & \frac{1}{m_{B R G_{2}}^{2}} & \cdots & 0 \\
\cdots & \cdots & \cdots & \cdots \\
0 & 0 & \cdots & \frac{1}{m_{B R G_{n}}^{2}}
\end{array}\right], \quad \hat{\delta}_{0}^{2}=\frac{\mathbf{V}^{\mathrm{T}} \mathbf{P V}}{n-k}
$$

and $\Delta x_{n}, \Delta y_{n}$ - approximate distance along the axis of abscissas and axis of ordinates, respectively, from the ship position before adjustment to $n$-th navigational mark of known coordinates (towards which the bearing has been determined); $\hat{\delta}_{0}^{2}$ - variance coefficient estimator (for calculations $\hat{\delta}_{0}^{2}=1$ has been adopted, assuming correctly selected values of the mean errors of bearings surveyed and thereby the determined elements of the weight matrix $\mathbf{P}) ; n$ - number of measurements; $k$ - number of unknowns; $D_{n}$ - approximate distance from the ship position before adjustment to $n$-th navigational mark of known coordinates (the mark towards which the bearing is determined).

\subsection{The process of developing sea navigational charts with the accuracy areas mapped on}

For the preparation of charts with the accuracy areas mapped on, three program applications have been used. Each of them is responsible for realization of the following assignments: 
- determining and recording mean errors of positions at nodes of the regular grid (data models use a 2D array) covering the water area investigated,

- setting out contour lines bounding areas of equal accuracy on the basis of the grid,

- developing of navigational charts with accuracy areas mapped on.

To perform the first assignment a special program application was developed in the integrated environment of Borland $\mathrm{C}++$ Builder 6.0. The application takes data concerning navigational marks out from the electronic navigational chart and for each node of the grid computes the mean position error. The input parameters for the calculations are as follows:

- $\varphi_{0}, \lambda_{0}$, and $\varphi_{\max }, \lambda_{\max }$ - geographical coordinates of the left bottom corner and the right top corner of the grid, respectively,

- $\Delta \lambda, \Delta \varphi-$ meridional and parallel, respectively, size of the mesh of the GRID,

- $r_{p}$ - limiting distance (radius) of searching for navigational marks,

- $\quad l_{z}$ - flag defining the computational mode; for $l_{z}=$ false - position fixed from two distances, for $l_{z}=$ true - position fixed from three and more distances (the option chosen in the application),

- $\quad m_{\alpha}$ - the mean error of setting out an angle with the use of a camera and $m_{G}$ defining the bearing with gyrocompass.

The output of the program is a file with records which include the following consecutively recorded information:

- $\varphi, \lambda$ - geographical coordinates of the grid node,

- $m_{p o s}$ - the mean error of the position at the node,

- $l_{z z}$ - number of marks taken to calculations.

Figure 3 presents the computational algorithm implemented to the application.

The second assignment, i.e. the determination of the accuracy areas from the file obtained applying the algorithm in Figure 3 is carried out by „MapInfo Vertical Mapper" program (www.mapinfo.pl/opro/analizy/vertical.php). The program provides output files of "mif" format with so-called map layers including geometrical description of contour lines, delimitating the accuracy areas of the mean position errors that successively does not exceeding 5, 10, 20, 50,100, 200, $500 \mathrm{~m}$. 


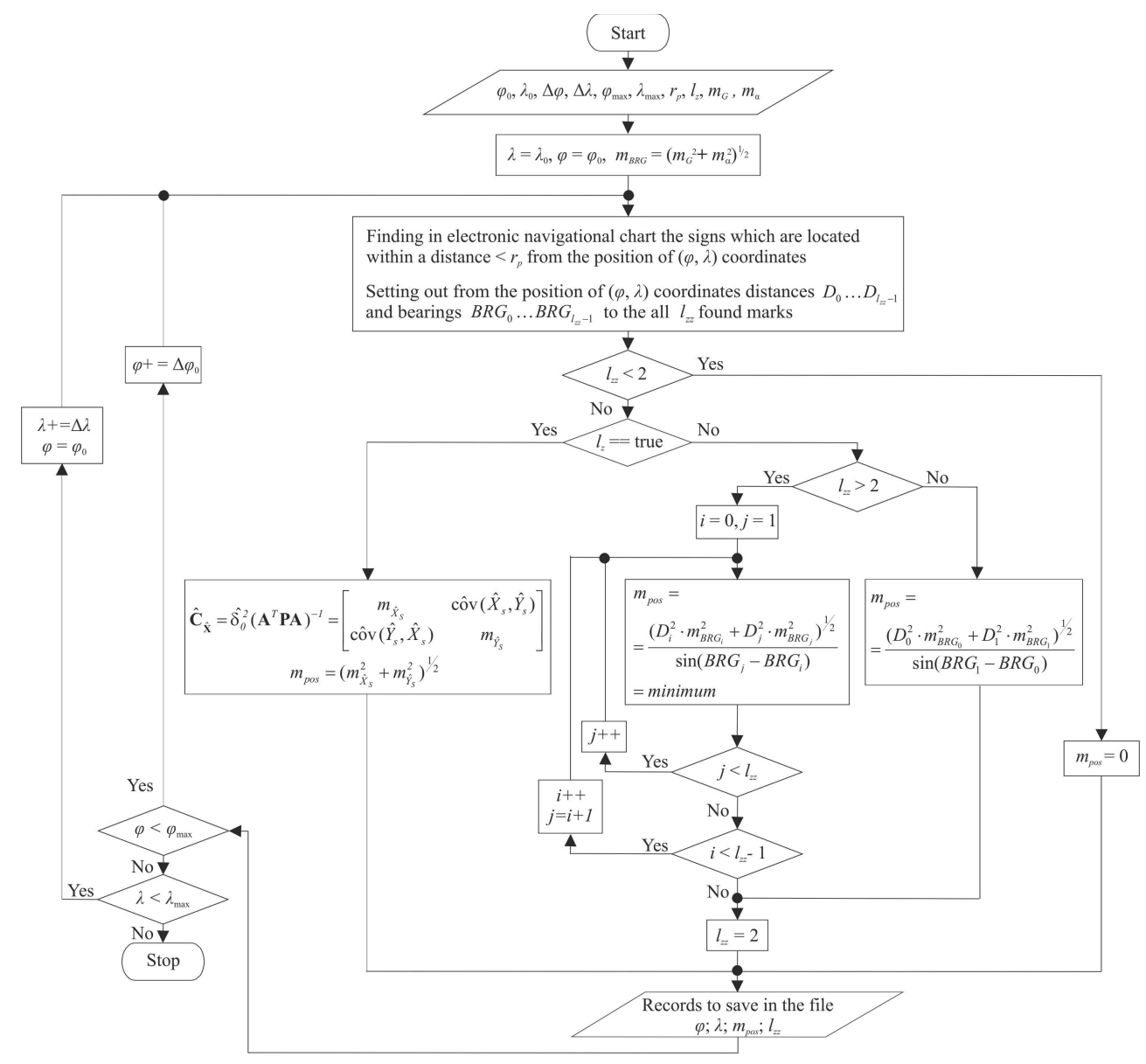

Fig. 3. Algorithm of setting out grid of the mean position errors

The authors' program „Planszet” is next used to conduct the third assignment, consisting in the preparation of navigational charts in Mercator projection with the accuracy areas mapped on.

\section{Results and discussion}

\subsection{Analysis of accuracy of angle measurement with Rolleiflex and Sony camera}

According to formula (1), the measurement resolution is proportional to the product of measurement distance and pixel's size in CCD matrix and inversely proportional to a focal length. For the focal length ranging from 300 to $500 \mathrm{~mm}$ the resolution is high, what guarantees good targets discrimination even at the optical visibility threshold. 
Decrease of the measurement resolution due to, e.g. a change of the focal length may affect unfavourably a process of navigational marks identification, especially of those which are located close to the observer.

Figures 4 and 5 present diagrams of the mean error $m_{\alpha}$ of the angle measured with Rolleiflex and Sony camera versus the distance $x$ measured in a CCD matrix. It has been assumed that the mean error of the focal length $m_{f}=0.0004 \mathrm{~m}$, mean error $m_{x}=6.8 \mu \mathrm{m}$ for Rolleiflex camera, and $m_{x}=5.94 \mu \mathrm{m}$ for Sony camera ( $m_{x}$ equal to the size of pixel in CCD matrix has been assumed).

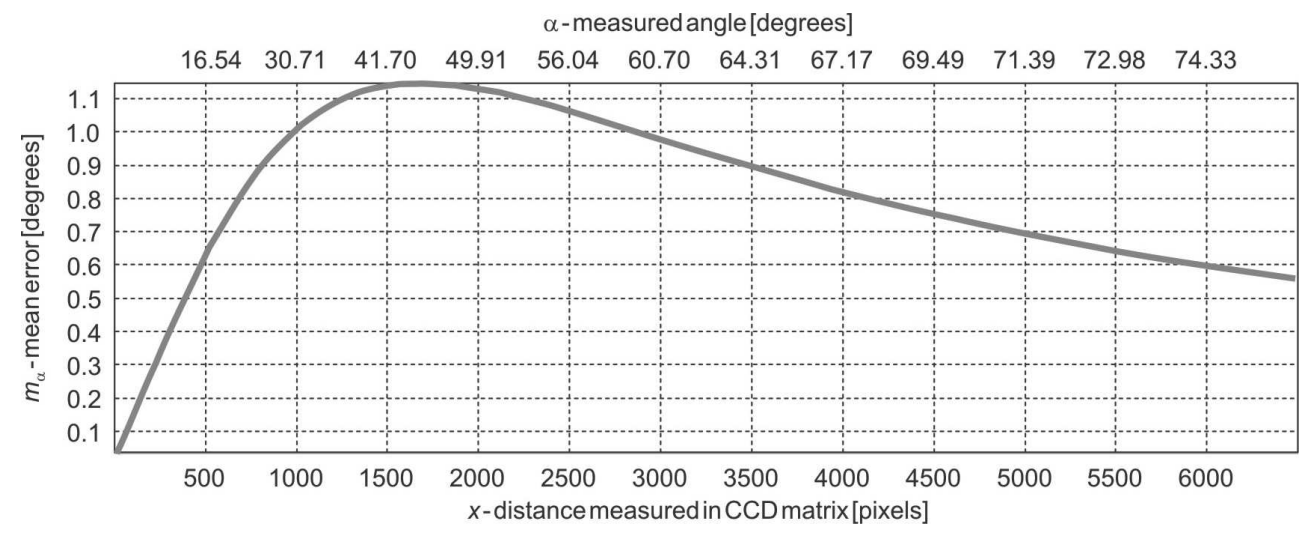

Fig. 4. Diagram of the mean error $m_{\alpha}$ of measured angle versus distance $x$, measured in the CCD matrix for Rolleiflex 6008 camera with P45 matrix (pixel dimension in the matrix is $6.8 \mu \mathrm{m}$, the focal length is set to $10 \mathrm{~mm}$ )

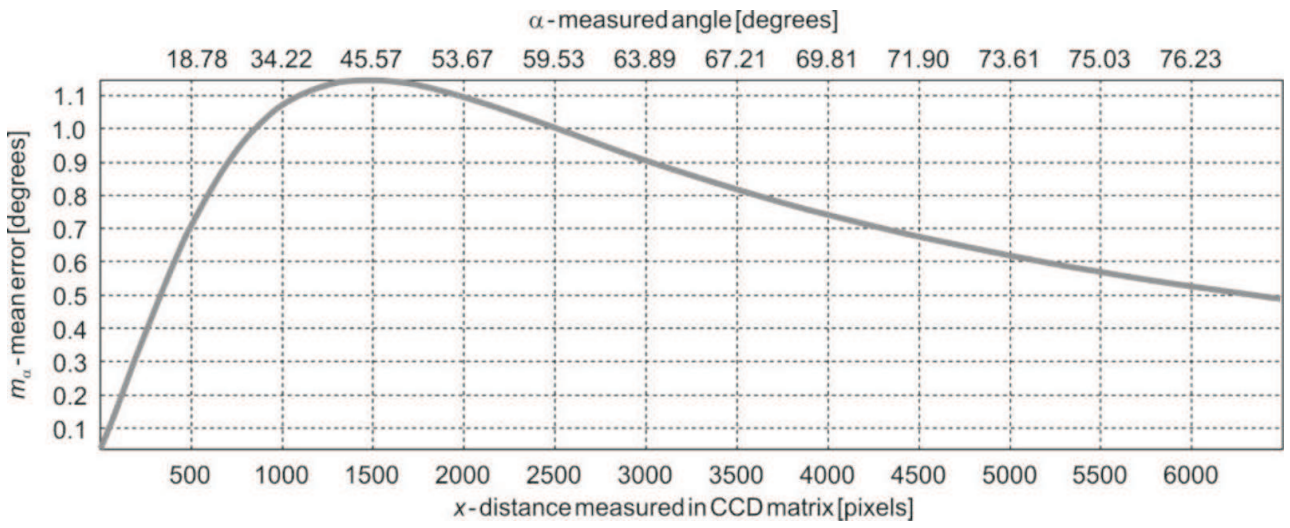

Fig. 5. Diagram of the mean error $m_{\alpha}$ of measured angle versus the distance $x$ measured in CCD matrix for Sony $\alpha 900$ camera with the matrix of resolution of $6096 \times 4056$ pixels and lens F4-5.6 G SSM (dimension of the pixel in the matrix is $5.94 \mu \mathrm{m}$, the focal length is set to $10 \mathrm{~mm}$ ) 
Analysis of the diagrams presented in Figures 4 and 5 indicate that cameras available on the market can provide accuracy of angle measurement at the level of $1^{\circ}$ already with the focal length of $10 \mathrm{~mm}$.

By increasing a focal length up to $400 \mathrm{~mm}$ for the Rolleiflex camera or up to $500 \mathrm{~mm}$ for Sony camera, measurement accuracy can be improved even up to $0.001^{\circ}$. However, it is necessary to take into account that increasing the focal length results in significant restriction of the observation sector. In the cases investigated the observation sector was only about $4^{\circ}$. Though it is of the minor size, for the survey taken from a distance of 12 nautical miles (ca. $22 \mathrm{~km}$ ) it enables observations of the coastal zone within about 8 cable-lengths (ca. $1500 \mathrm{~m}$ ).

\subsection{Analysis of the accuracy areas of the ship position fixed by means of bearings surveyed with camera}

The accuracy areas have been developed for the positioning system, consisted of a camera coupled with a gyrocompass. The positions were set out basing on fixed navigational marks located within the Gulf of Gdansk. It has been assumed that the mean errors $m_{\alpha}$ of the angles determined by means of a camera as well as the mean errors $m_{G}$ of bearings determined with a gyrocompass are equal and amount to $0.5^{\circ}$. A limiting distance $r_{p}$ of searching for navigational marks is 12 nautical miles (ca. $22 \mathrm{~km}$ ).

Figure 6 presents the main program window when computing the mean error of the position, defined in a grid node. In the case shown the bearings towards four navigational marks are taken for the computation. Only those marks are located closer than 12 nautical miles from the node under consideration.

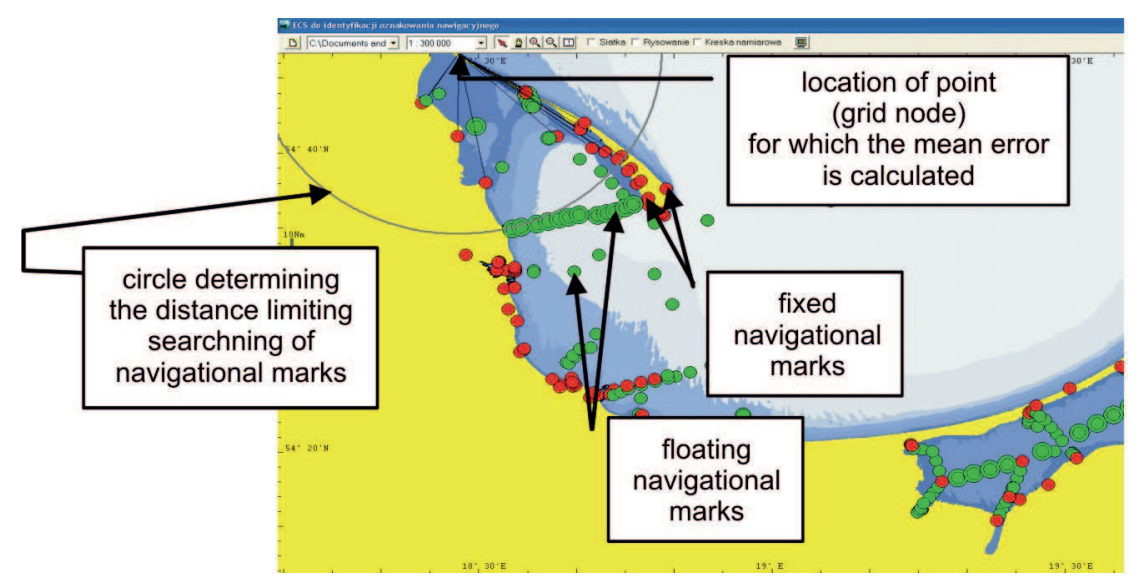

Fig. 6. The main program window appearance on computation of the mean error for the grid node 
a)

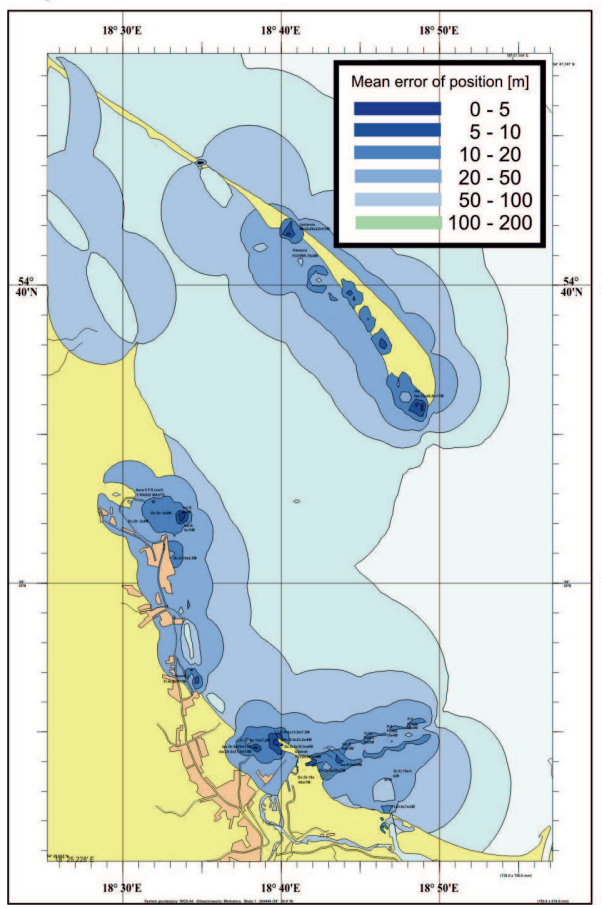

b)

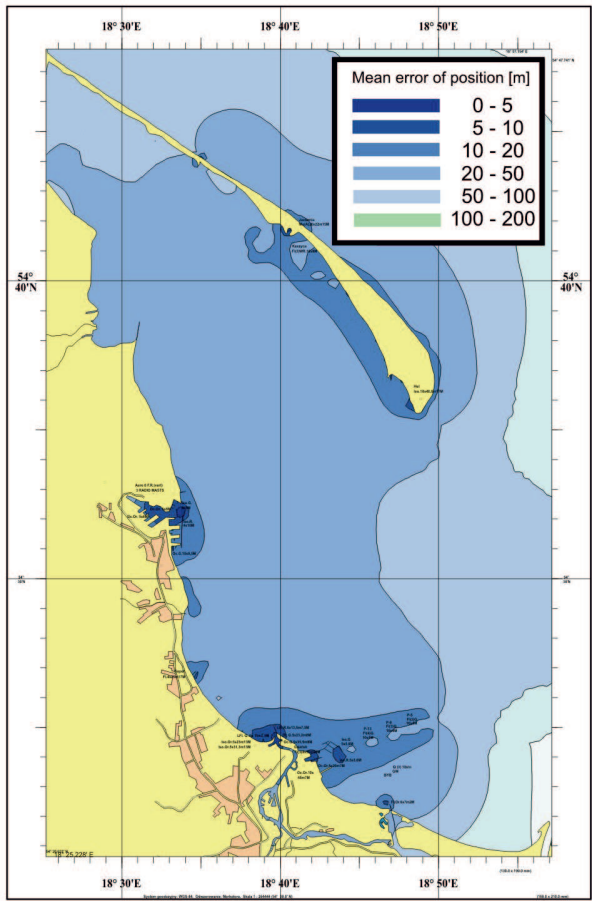

Fig. 7. Chart with accuracy areas of positions: a) determined from two bearings, b) determined from three and more bearings (after adjustment)

\section{Conclusions}

1. The measurement system developed at the Polish Naval Academy is based on high resolution cameras available on the market. It guarantees high accuracy of measurement of bearings within the limits of the navigational marks and lights optical visibility range, i.e. with very good visibility the optical range can reach even up to 30 nautical miles (ca. $55 \mathrm{~km}$ ).

2. Accuracy of an angle measured with the use of the system investigated can be improved by increasing a focal length of the camera optical system and by applying the navigational device for setting out more precisely the north direction.

3. The camera-gyrocompass system enables to measure bearings from a ship towards the navigational mark observed. Results of the measurements in conjunction with coordinates of the marks' positions obtained from electronic navigational chart may be useful for the computation of the ship's position coordinates.

4. Accuracy of the obtained position is better than the required one in coastal navigation, also in port approaching and inside port navigation. On the grounds of IMO Res. A.815(19) one may state that the navigational system which provides accuracy better than 2 nautical miles $(\mathrm{P}=95 \%)$ is sufficient in coastal navigation. After all, as it appears in practice and comes out from the requirements of GMDSS 
NAV 47/7/1 ANNEX2 p.5 of IMO, accuracy in fixing positions in this phase of navigation should be better than $100 \mathrm{~m}(\mathrm{P}=95 \%)$ (IMO, 1995; 2001).

5. It should be noted that two essential factors affecting optical measurement accuracy, i.e. distortion of lens and refraction of atmosphere have not been reported in the research. Therefore the next examinations of the gyrocompass - camera system should be carried out upon manoeuvring of the ship in a coastal zone, in the daylight and at night, in various visibility conditions.

\section{Acknowledgments}

The paper was prepared in framework of the statutory research on „Application of the optical systems to automation of coastal navigation processes" at the Institute of Navigation and Hydrography, Polish Naval Academy, Gdynia.

\section{References}

Austin D., Kouzoubov K., (2002): Robust, long term navigation of a mobile robot, Proceedings of IARP/IEERAS Joint Workshop on Technical Challenges for Dependable Robots in Human Environments, pp. 67-72.

Benhimmane S., Mailis E., (2006): A new approach to vision-based robot control with omni-directional cameras, Proceedings of IEEE International Conference on Robotics and Automation, Orlando, pp. 526-531.

Bianco G., Zelinsky A., (2000): Real time analysis of the robustness of the navigation strategy of a visually guided mobile robot, Proceedings of International Conference on Intelligent Autonomous Systems, Venice pp. 3778-3783.

Davison A.J., (2003): Real-Time simultaneous localization and mapping with a single camera, Proceedings of IEEE International Conference on Computer Vision, Vol. 2, Nice, pp. 1403-1410.

Hoshizaki T., Andrisani I.D., Braun A.W., Mulyana A.K., Bethel J.S., (2004): Performance of integrated electro-optical navigation systems, Navigation, Journal of the Institute of Navigation, Vol. 51, No 2, 2004, pp. 101-129.

IMO, (1974): International Convention for the Safety of Life at Sea, SOLAS 74/81/83.

IMO, (1979): Performance standards for gyro-compasses, Resolution A.424.

IMO, (1995): World-wide radionavigation system, Resolution A.815(19).

IMO, (2001): NAV 47/7/1, Annex 2.

Jagielski A., (2007): Geodesy II (in Polish), GEODPIS, $2^{\text {nd }}$ Edn, Krakow.

Jędryczka R., (1999): Semi-Automatic Exterior Orientation Using Existing Vector, OEEPE Official Publication, No 36.

Kopacz Z., Morgaś W., Urbański J., (2003): Assessment of accuracy position of the ship (in Polish), Polish Naval Academy, $2^{\text {nd }}$ Edn, Gdynia.

Knight J., (2002): Robot navigation by active stereo fixation. Robotics Research Group, Department of Engineering Science, University of Oxford, Report No. OUEL 2220/00.

Montemerlo M., (2003): FastSLAM: A Factored Solution to the Simultaneous Localization and Mapping Problem with Unknown Data Association, $\mathrm{PhD}$ Thesis, Robotics Institute, Carnegie Mellon University, Pittsburgh.

Mouragnon E., (2006): Real time localization and $3 D$ reconstruction, Proceedings of IEEE International Conference on Computer Vision and Pattern Recognition, Vol. 1, pp. 363-370.

OEEPE, (1999): Official Publication, No 36. 
Robert P.C., ( 2004): Casella G. Monte Carlo statistical methods, Springer-Verlag, ISBN 0-387-212339-6.

Ryynanen K., Vehkaoja A., Osterberg P., Joro R., (2007): Automatic recognition of sector light boundaries based on digital imaging, IALA Bulletin, Issue 1/2007, pp. 30-33.

Snyder F.D., Morris D.D., Haley P.H., Collins R.T., Okerholm A.M., (2004): Northrop Grumman. Autonomous River Navigation, Proceedings of SPIE, Mobile Robots XVII, 2004, pp. 221-232.

Sridharan M., Kuhlmann G., Stone P., (2005): Practical vision-based Monte Carlo localization on a legged robot, Proceedings of IEEE International Conference on Robotics and Automation, pp. 3366-3371.

Stachniss C., Hanel D., Burgared W., (2004): Exploration with active loop-closing for FastSLAM, Proceedings of IEEE/RSJ International Conference on Intelligent Robots and Systems, Vol. 2, pp. 1505-1510.

Stronger D., Stone P., (2007): Selective visual attention for object detection on a legged robot, Springer-Verlag.

Wang C., (2004): Simultaneous Localization, Mapping and Moving Object Tracking, PhD Thesis, Robotics Institute, Carnegie Mellon University, Pittsburgh.

Winters N., Gaspar J., Grossmann E., Santos-Victor J., (2001): Experiments in visual-based navigation with an omnidirectional camera, Proceedings of the IEEE ICAR 2001 Workshop: Omnidirectional Vision Applied to Robotic Orientation and Nondestructive Testing, Budapest, pp. 223-270.

Wiśniewski Z., (2005): Adjustment computations in geodesy (in Polish), University of Warmia and Mazury, $1^{\text {st }}$ Edn, Olsztyn.

Yuanand C., Medioni G., (2006): 3D reconstruction of background and objects moving on ground plan viewed from a moving camera, Proceedings of IEEE International Computer Society Conference on Computer Vision and Pattern Recognition, pp. 2261-2268.

Dokładność wyznaczania pozycji statku z pomiarów namiarów wykonanych kamerą

\author{
Krzysztof Naus, Mariusz Wąż \\ Instytut Nawigacji i Hydrografii Morskiej \\ Akademia Marynarki Wojennej w Gdyni \\ ul. Smidowicza 69, 81-103 Gdynia \\ e-mail: K.Naus@amw.gdynia.pl,mwaz@amw.gdynia.pl
}

\title{
Streszczenie
}

W artykule przedstawiono opis badań mających na celu ustalenie możliwości określania współrzędnych pozycji statku z wyników pomiarów namiarów optycznych na znaki nawigacyjne wykonanych kamerą CCD. Jako podstawowe kryterium przyjęto dokładność określania współrzędnych pozycji statku zwymiarowaną wartością błędu średniego.

W pierwszej części artykułu przedstawiono metodę wyznaczania rozdzielczości i błędu średniego pomiaru kąta kamerą oraz metodę wyznaczania błędu średniego współrzędnych pozycji z dwóch i więcej namiarów. Opisano trzy aplikacje programowe służące do przygotowywania morskich map nawigacyjnych z naniesionymi obszarami dokładności.

W drugiej części zaprezentowano wyniki z badania dokładności określania współrzędnych pozycji statku na Zatoce Gdańskiej z namiarów zmierzonych kamerą firmy Rolleiflex i Sony. Ukazano je w postaci wykresów błędu średniego pomiaru kąta oraz w postaci morskich map nawigacyjnych $\mathrm{z}$ naniesionymi obszarami dokładności.

W części końcowej, opierając się na wynikach badań przeprowadzono dyskusję dotyczącą oceny przydatności kamer CCD do automatyzacji procesu prowadzenia morskiej nawigacji przybrzeżnej. 